\title{
Returning to learning: what are the academic development needs of mature and part-time students? What works to support and retain these students?
}

\author{
Louise Frith \\ University of Kent, UK
}

Allia Wilson

University of Kent, UK

\section{Abstract}

This paper considers the support and retention of mature and part-time (MaP) students. It analyses the specific academic development needs of MaP students based on Wenger's model of learning (1998) which puts the academic learning needs of students into three broad categories; the first is academic confidence and learner identity, the second is the need for MaP students to integrate and build a sense of community, and the third is for these students to overcome anxiety through practice and practical considerations. Then an Appreciative Inquiry (Cooperrider et al., 2008) approach is used to develop the University of Kent's Student Learning Advisory Service (SLAS) MaP programme called VALUE MaP. The programme offers; self-assessment of needs, one to one advice and targeted study skills sessions. The conclusion points to the positive responses received from MaP students about the programme but also acknowledges that more could be done; perhaps through reflection on students' prior knowledge, a stronger emphasis on building social learning networks, and the increased use of technology.

Keywords: mature and part-time students; identity; community; practice.

\section{Introduction}

An outcome of the UK government's Widening Participation agenda is the emergence of a 'new constituency of learners' (MacDonald and Strutta 2001, p.205). Two of these constituencies are mature and part-time students, who are now significant minority groups 
within the UK student population. The focus of recent government policy has been on improving non-traditional students' access to university, but there has not been the same government drive to ensure these students participate, achieve and are retained at university. In this paper, mature and part-time students are considered together because, although they are two distinct groups, their access to on-campus learning development support is similarly restricted. At the university, across two campuses (at Canterbury and Medway) there are a total of 16,463 undergraduate students of whom 3,286 are part-time, of these more than $85 \%$ are also mature (over 21 ). This is a very significant overlap, thus for the purposes of providing a support initiative and for this research, the two groups have been combined.

There are significant factors which inhibit mature and part-time students' full engagement with higher education; mature students will have had a break in their formal education which can often result in a loss of confidence, whilst part-time students are often juggling other commitments such as childcare, work or dealing with a long-term health issue. Reay et al. (2005) comment that these factors mean that the decision for mature and part-time students to participate in higher education is much riskier than it is for younger full time students. In addition mature students often find it difficult to integrate in classes where the majority of students are school-leavers. Trotter and Cove's research (2005, p.35) reported that mature students felt excluded from the out-of-class social interactions that younger students took for granted and they felt that there was a 'big divide' between their experience and that of their younger counterparts. In response to Tinto's work on student retention (1998), Ashar and Skenes' data (1993) shows that smaller class sizes are a crucial factor in retaining mature students because greater integration and communication is possible in smaller classes. Mature students may also feel less academically capable having left school some years previously or having undergone work-based learning which they perceive as academically inferior to a three-year university degree. Stevenson and Clegg (2013) note that mature students have often previously underachieved academically and are also often from lower socio economic groups than younger students. Younger part-time students may feel less integrated since they are not entitled to on-campus accommodation and therefore find it harder to build up a social network amongst their peers. Indeed Davies (1999, p.144) comments that part-time higher education is usually a 'half empty experience, rather than a half full version of the real thing'. 
These factors indicate that the support and retention of MaP students should be targeted to meet their specific needs. In fact in 2005 the National Institute of Adult Continuing Education (NIACE) expressed concern that provision for part-time and mature students is often the least resourced, least valued and least well understood. The Student Learning Advisory Service (SLAS) has responded to this by developing and devising the VALUE MaP Programme as a series of 12 academic development sessions specifically aimed at MaP students registered on University of Kent courses (see Appendix 2). In line with other specific retention and support initiatives developed by SLAS, the Programme was given the VALUE label (Value Added Learning in University Education).

\section{Methodology}

For this study, new-entrant MaP undergraduates were surveyed (this was done in adherence to the university's ethical approval). Data was gathered in three ways; the age, gender and programmes of study for which the students were enrolled on was collected from the university's Student Data System. Information about the academic development sessions and levels of participation in these workshops came from SLAS' records. This revealed that in the total of $12 \times 2$ sessions offered on both campuses, 347 students attended. Formal and anonymous feedback was gathered from 72 students who had attended at least one session. This was done via online surveys after the last of the workshops in the Autumn Term and then again after the Spring Term sessions (see Appendix 1 for more details of the questions used in these surveys). Finally, qualitative information about mature and part-time students' academic development needs and evaluations of their experiences was gathered through twelve unstructured interviews before and after the VALUE MaP programme. The interviews were carried out by 4 SLAS staff, however, in order to avoid students being influenced by knowing the interviewer, staff who had taught the VALUE MaP sessions did not conduct the interviews. The questions used in these interviews were based on five key questions which were developed by the learning development team at Kent:

1. How do you identify yourself (say what you do) to others?

2. What are the reasons that you decided to become a mature or part-time student?

3. Do you feel that you belong to part of a learning community at the university? 
4. What practical issues do you face as a mature or part-time student that you think other students do not face?

5. Do you feel supported by your friends and family as a student?

The data generated from the surveys and interviews was used to construct themes by which to examine the VALUE MaP programme, and an Appreciative Inquiry (AI) approach was used to see what works in terms of supporting MaP students at university. Al stems from Organisational Development (OD) theory, but differs from other OD approaches which tend to focus on solving problems. Therefore the VALUE MaP programme resisted seeing MaP students as problems; instead following the Al model, it established an 'affirmative topic', i.e. the retention and academic achievement of mature and part-time students. The programme then focused on these students' strengths and used collaboration with these students to develop the VALUE MaP programme.

Profile of Mature and Part-time students at the university: the context for Academic Year 2009-2010.

\begin{tabular}{|l|l|l|}
\hline Total number of undergraduates & 16,463 & $\%$ \\
Full-time undergraduates & 13,177 & $80 \%$ \\
Part-time undergraduates & 3,286 & $20 \%$ \\
\hline Total number of undergraduate new entrants & 6,096 & \\
Full-time & 5,119 & $84 \%$ \\
Part-time & 977 & $16 \%$ \\
\hline Undergraduate part-time new entries by gender & & \\
Female & 483 & $49 \%$ \\
Male & 494 & $51 \%$ \\
\hline Undergraduate, part-time new entries by faculty & & \\
Sciences & 54 & $6 \%$ \\
Humanities & 533 & $54 \%$ \\
Social Sciences. & 342 & $35 \%$ \\
Other & 48 & $6 \%$ \\
\hline Undergraduate, part-time new entries by age & & \\
$<21$ & 107 & $11 \%$ \\
$21-24$ & 169 & $17 \%$ \\
\hline
\end{tabular}




\begin{tabular}{|l|l|l|}
\hline $\begin{array}{l}=\text { and }>25 \\
\text { NK }\end{array}$ & $\begin{array}{l}693 \\
8\end{array}$ & $70 \%$ \\
\hline Undergraduate, part-time new entries by campus & & - \\
Canterbury & 596 & $71 \%$ \\
Medway & 208 & $22 \%$ \\
Tonbridge & 8 & $1 \%$ \\
Associated Colleges & 165 & $16 \%$ \\
\hline
\end{tabular}

(University Statistic - Blue Book - 2009-10)

\section{Students' academic development needs}

\section{Perceptions of identity}

A major concern for mature and part-time students is lack of confidence in their academic ability. This often has a lot to do with the students' sense of self identity: much has been written about mature students' conceptions of identity as a barrier to full participation in higher education. Reay (2002) refers to it as an imposter feeling. Crossan et al. (2003) say that for some mature students, a rejection of education in earlier experiences can lead to mature students having a fragile sense of student identity. This is reinforced by Ramsay (2004) who says previous academic failure can become part of mature students' learner identity. Often MaP students see themselves as parents or employees but not as students or, as Christie et al. (2005) put it, they see themselves as day students returning to other identities when they are not at university. One mature student at Kent said:

I've been working for 12 years already so I think of myself as a youth worker, not a student.

Anxiety over the resumption of learning is also a common feature: many MaP students will report a long gap, often of many years, since their last formal learning experience. This is not entirely surprising, given that the average age of a VALUE MaP student is 41 , with over half the students in the 30-49 age group and another $25 \%$ over the age of 50 . Sitting in a classroom that feels as if it is full of 18-20 year olds, therefore, can seem like being back at school. Some mature students may have left formal education prematurely because of personal circumstances - for example, one student reports: 
I had to give up studying when I was 19 because I got pregnant.

Many of those returning to study have a sense that they are being required to move outside their 'comfort zone' and will talk about the loss of control they felt when they first started in higher education - they may feel personally 'de-skilled' as they move back into what they see as the role of the student-novice. Although transition into university is unsettling for many students regardless of whether or not they are mature or part-time, transition for MaP students is often more complex. The key issue for MaP students is about building up levels of confidence and enabling them to navigate a path successfully through these perceived changes in status and self-identity, precisely so they can see the transition into higher education as a positive achievement that will enhance and not diminish their sense of self-worth.

\section{Community of learners}

Belonging to a community of learners has been demonstrated to be instrumental in students' success. Wenger (1998) talks of the 'social phenomena of learning' and goes on to say that the most transformative learning is social learning. Tutors thus need to be aware of the importance of this social dimension and their own role in the social network and the part they play in the creation of a supportive environment for peer-group learning. Research by Parmer and Trotter (2005) shows that universities which focus on pre entry information and inductions to help students make friends have significantly better retention rates than universities which do not prioritise induction.

Wenger (1998) suggests that there are three key components in a functioning community of practice (figure 1 below). One major issue with this model of community of practice, however, is that MaP students frequently report feeling isolated from other students on their programme of study. Mature students cannot, or maybe do not want to, get involved in the same social activities that attract the majority of younger students:

I don't really want to talk with the younger students about what they did last night...they can't relate to me and my experiences of life, they just treat me like their mum! 


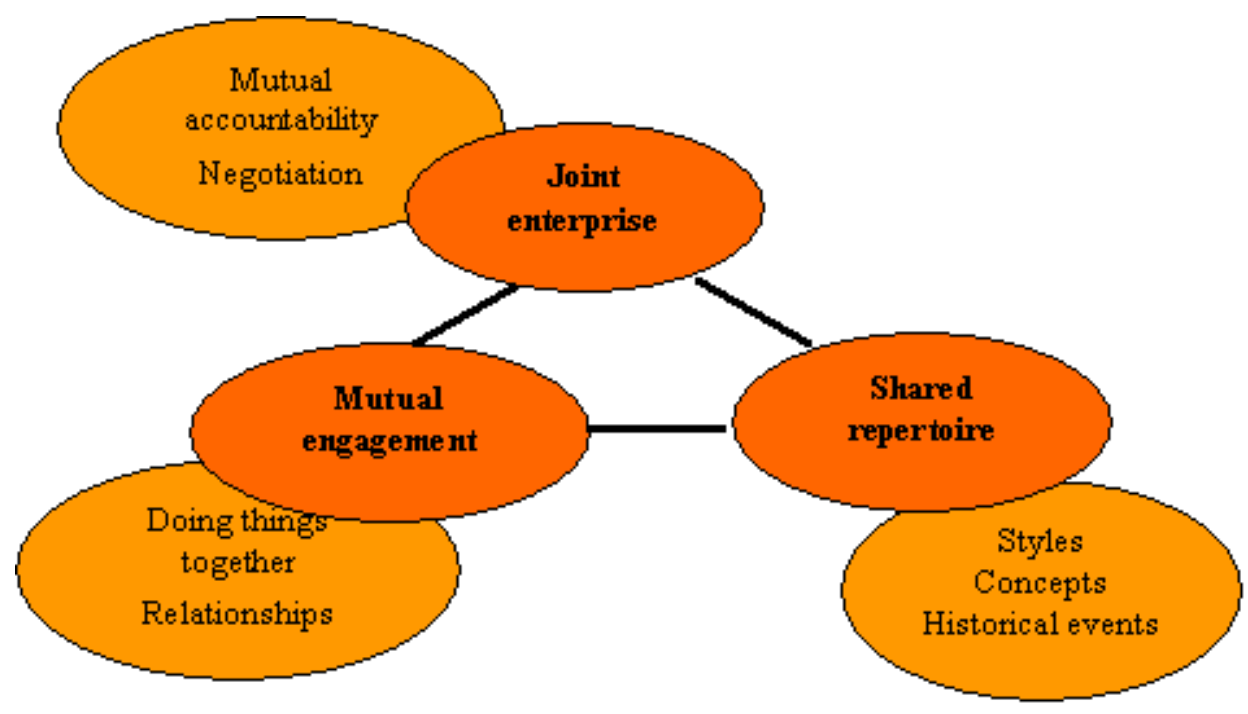

Figure 1. Wenger (1998).

All of the mature students interviewed were living away from campus, so they had little or no informal contact outside the classroom with other students who live in university or share student accommodation. MaP students feel that this puts them at a distinct disadvantage because they are not able to access informal learning with the same ease as younger, full-time students.

\section{Overcoming practical barriers}

Another significant consideration for many mature and part-time students is their capacity to overcome practical barriers to learning. Timing, travel arrangements, other priorities, and responsibilities loom large for this group of students and affects their choice of where to study (Lucas, 1990). Interviews with MaP students at the start of their degree programme are frequently dominated by their anxieties about balancing these competing responsibilities, often compounded by the complications and costs of travelling into a campus which could be some distance from home.

It takes me nearly two hours to get into university. I can't just come in for one session. I have to take everything with me and camp at the University for the day to make it worthwhile. 
Issues of child care are especially important for student parents. Mothers, in particular, often have to re-negotiate household responsibilities with their partner and older children. This can lead to tension as old habits are often hard to change.

l've always done everything at home so it's hard to get them [her family] to help.

Further pressure may be put on part-time and mature students by the demands of balancing paid work with study which can mean that they are less able to access some of the extra support and personal development experiences available at university. Even issues as seemingly peripheral as the lack of adequate IT training can place these students at a further disadvantage as they are quickly confronted with the need to gain access to internet resources. For some of these students, something as mundane as a routine trip to a modern IT-focused library can feel utterly overwhelming.

\section{Background information about VALUE MaP}

The aim of the VALUE MaP programme is to help mature and part-time students 'feel at home' in a higher education environment so that they can develop the effective learning strategies needed for successful completion of the course. The sessions are not disciplinespecific, but concentrate on 'learning to learn' in an academic environment.

Students can choose a number of VALUE MaP sessions according to their self-identified learning development needs. Session tutors are aware of the needs of this particular cohort and thus select suitable materials and teaching methods to help students settle into university life. The VALUE MaP sessions run for three consecutive weekends at the start of the Autumn Term.

The classes are small to facilitate discussion and there is an emphasis on communicative learning so that within the session a community can be built. Most workshop days ended with 'study clinics' to give those students who find it difficult to access the Student Learning Advisory Service during normal office hours the option of meeting with a learning advisor and of discussing their own individual learning needs. 


\section{How VALUE Map addresses identity}

The VALUE programme addresses these issues of time-lapse in education and interrupted study through the 'Introduction to University' session. This session places emphasis on discussion of students' previous experiences and takes a 'strengths based' (Staron, 2010) approach to reviewing students' academic skills. Cowan ( $p$ 76, 2011) describes this as:

Enabling learners to experience, feel and appreciate themselves as a knower.

This helps students to focus on areas where they have some experience or expertise, such as time management, meeting deadlines and being prepared to ask questions. The programme focuses on building academic confidence for students who may not have participated in formal learning for some time, recognising that:

Students entering into these programs without having learned the skills of selfdirected inquiry will experience anxiety, frustration, and often failure, and so will their teachers. (Knowles, 1975, p.15)

At the same time, however, these initial sessions also enable participants to work at the process of establishing a confident new self-identity as a student. As Wenger argues (1998, p.56), this is most effectively formed through active participation: in this case, mature students form a new peer group to support each other as they explore shared concerns. Often it is enough simply to articulate these hopes and fears to start the process of transition into the first year of higher education, moving gradually from dependence to independence. This provides a starting point for integration into the university learning environment, as students mix with other like-minded individuals and develop a stronger sense of academic confidence. This is critical for academic success if mature students are to build on their initial motivation, and ultimately complete their studies.

\section{How the VALUE programme addresses community}

The VALUE programme aims to facilitate collaboration and create a sense of community through classroom activities; session plans are negotiated with students at the beginning of each class. Sessions begin with a review of students' previous experience of the activity under discussion, such as note taking, academic writing or reading. Students are encouraged to reflect on their successes in these areas and in this way build up a 'shared 
repertoire' (Wenger, 1998) of transferable academic skills. In addition, students are given in-class activities such as comparing notes from reading, discussing speed reading techniques, or designing a poster with their top tips for essay writing. These activities require discussion with other students and so help to build up a sense of community through 'mutual engagement' and 'joint enterprise' (Wenger, 1998). Some of the work that students have produced during these sessions has been of high quality, therefore it has been made available for other students via the SLAS resources website (e.g. revision notes for sports studies). These sessions provide the opportunity for MaP students from across departments to mix and develop informal socio-educational peer support networks.

\section{How VALUE MaP addresses practical barriers}

Sessions on time management tend to be popular and produce a high level of debate amongst the students. This is often an area when students can contribute freely from their own expertise and this experiential knowledge is captured in an exercise where students are asked to produce posters on time management.

The need to combine adult responsibilities with the practical constraints of formal study lead on to another key area for negotiation: local data shows that MaP students are most likely to attend extra academic development sessions on Saturday; however, they are unlikely to make the journey for just one hour, therefore sessions are scheduled for four consecutive hours so that students can set aside a whole morning for their study, making childcare and travel arrangements worthwhile. However, there remain students for whom these times are not suitable, therefore they have the option to attend the standard SLAS workshops open to all students either on Wednesday afternoons or twilight sessions on Monday evenings.

\section{Discussion}

The VALUE MaP programme has been deemed by the university as successful as sessions are mostly well attended and student feedback is positive. Most of the students reported that they appreciated the opportunity to 'brush-up' their skills as well as meet other MaP students. Overall, therefore, students were very happy with the content, structure and timing of the sessions. Feedback received from the participants has provided 
valuable insight on each of the three areas discussed in this paper. In particular, students noted that their levels of confidence had increased significantly - as one student said:

I think that the sessions help to give confidence and provide valuable information about studying. (Online Survey, 2010)

Another student made specific reference to her feeling of empowerment as a result of the VALUE MaP sessions: she said it was 'Extremely useful. Very empowering!!' (Online Survey, 2010). Many students also commented on becoming a member of a learning community through engagement with VALUE MaP. As one student put it:

I attended all of the Saturday sessions at Medway in October/ Feb/ March. Found them very useful and also it was good to meet other mature students from different courses. (Student Interview 2010)

Students particularly enjoyed meeting students from different disciplines and backgrounds; as Wenger (1998) suggests, diversity is a key element in the formation of a strong and dynamic community:

I enjoyed mixing with other students from other courses. (Online Survey 2010)

This element of confidence and identity is vital to the future academic success of the programme.

Students responded well to the practical arrangements and many students found it useful to have sessions bunched:

It is good to have the sessions timetabled together as it makes my arrangements easier. (Student Interview, 2010)

Students also commented positively on the practical sessions such as IT skills:

The IT session told me things I had never heard before; marks went up afterwards. (Online Survey, 2010) 


\section{Conclusion}

Support and retention of mature and part-time students is a key indicator of a university's commitment to widening participation. The barriers that mature and part-time students face are categorised into three main areas; fragile student identity, lack of a sense of belonging to a learning community, and anxiety about the practical barriers to learning. The university is addressing these concerns through its VALUE MaP programme which is a supportive and developmental learning intervention for mature and part-time students, offering a means by which they can establish a positive student identity and a sense of belonging to an academic community through participation. Recognition of students' prior experiences and existing skills are valued and built upon. The anxiety which MaP students experience at the start of a programme of study is countered by targeted practical sessions, sensitive tutors, and a supportive environment of peers. Furthermore, students' academic confidence grows through joint enterprise and mutual engagement in class-based activities. The VALUE MaP programme will continue next year and there are plans to improve it. Firstly, through strengthening reflection on students' prior knowledge to enhance students' positive identity with learning; also by putting a greater emphasis on building social learning networks; and finally with the increased use of technology, such as e-portfolios for maintaining contact between students and enabling them to record a wider range of their achievements.

\section{References}

Ashar, H. and Skenes, R. (1993) 'Can Tinto's student departure model be applied to nontraditional students?', Adult Education Quarterly, 43(2), pp. 90-100.

Christie, H., Munro, M. and Wager, F. (2005) 'Day students in higher education: widening access students and successful transitions to university life', International Studies in Sociology of Education, 5(1), pp. 3-29.

Cooperrider, D, Whitney, D. and Stavros, J. (2008) Appreciative inquiry handbook. $2^{\text {nd }}$ edn. Brunswick, $\mathrm{OH}$ : Crown custom publishing, Inc. 
Cowan, J. (2011) 'Creating a buzz - 'Lifewide Learning': the need for a radically revised pedagogy', Student Lifewide Development Symposium. Aston University, Birmingham 1 March.

Crossan, B., Field, J., Gallacher, J. and Merrill, B. (2003) 'Understanding participation in learning for non-traditional adult learners: learning careers and the construction of learning identities', British Journal of Sociology of Education, 24(1), pp. 55-67.

Davies, P. (1999) 'Half full, not half empty: a positive look at part-time higher education', Higher Education Quarterly, 53(2), pp. 141-155.

Knowles, M. (1975) Self-directed learning. A guide for learners and teachers. Englewood Cliffs: Prentice Hall/Cambridge.

Lucas, S. (1990) 'Open college and the transition to university', Journal of Access Studies, 5(1), pp. 35-46.

Macdonald, C and Stratta, E. (2001) 'From access to widening participation: responses to the changing population in higher education in the UK', Journal of Further and Higher Education, 25(2), pp. 249-258.

National Institute of Adult Continuing Education (NIACE) (2005) Policy briefing to Westminster Hall Adjournment Debate. 22 June 2005.

Parmer, D. and Trotter, E. (2005) 'Keeping our students: identifying factors that influence student withdrawal and strategies to enhance the experience and retention of first year students', Learning and Teaching in the Social Sciences, 1(3), pp. 449-168.

Ramsay, E. (2004) 'Blurring the boundaries and re-thinking the categories: implications of enabling education for the mainstream post-compulsory sector', Australian Journal of Adult Learning, 44(3), pp. 273-305.

Reay, D. (2002) 'Class, authenticity and the transition to higher education for mature students', Sociological Review, 50(3), pp. 398-418. 
Reay, D., David, M. and Ball, S. (2005) Degrees of choice: social class, race and gender in higher education. Stoke-on-Trent: Trentham.

Staron, M. (2010) 'Life-based learning model - a model for strength based approaches to capacity development and implications for personal development planning', Student Lifewide Development Symposium. Aston University, Birmingham 1 March.

Stevenson, J. and Clegg, S. (2013) "My past is a double edge sword': temporality and reflexivity in mature learners', Studies in Continuing Education, 35(1), pp. 1-13.

Tinto, V. (1998) 'Colleges as communities: taking research on student persistence seriously', The Review of Higher Education, 21(2), pp. 167-177.

Trotter, E. and Cove, G. (2005) 'Student retention: an exploration of the issues prevalent on a healthcare degree programme with mainly mature students', Learning in Health and Social Care, 4(1), pp. 29-42.

University Statistic - Blue Book - 2009-10 (available on request from the University Planning and Business Information Office)

Wenger, E. (1998) Communities of practice: learning meanings and identity. Cambridge: Cambridge University Press.

\section{Author details}

Louise Frith is a Student Learning Adviser specialising in academic and reflective writing.

Allia Wilson is the Student Learning Advice Service Manager specialising in student to student support and language development. 


\section{Appendix 1}

\section{Questions for online survey for VALUE MaP students}

1. Under which department do you study?

2. What session(s) did you attend?

3. On which campus was the session held?

4. On what date was the session held?

5. Who ran the session?

6. How did you find out about this session?

7. Did the session fulfil your expectations?

8. Was the session useful?

9. Did you learn anything new?

10. Is there anything that should be changed?

11. What other subjects would you like us to cover?

12. Please rate the following using this scale:

- The length of the session.

- The pace of the session.

- The materials/resources provided.

- The delivery of the session.

13. Have you got any comments or questions? Is there anything more we can do to help? 
Appendix 2: VALUE MaP workshop programme

\begin{tabular}{|c|c|c|}
\hline Workshop & Canterbury & Medway \\
\hline $\begin{array}{l}\text { WSHOP300 } \\
\text { Getting started at University: understanding what to } \\
\text { expect } \\
\text { and what is expected of you: seminar lecture, } \\
\text { assignments, } \\
\text { assessment, work load, etc. }\end{array}$ & $\begin{array}{l}\text { Sat } 5 \text { Oct } \\
2013 \\
09: 30- \\
10: 30 \\
\text { Room: GS3 }\end{array}$ & $\begin{array}{l}\text { Sat } 12 \text { Oct } \\
2013 \\
09: 30-10: 30 \\
\text { Room: M1- } \\
22\end{array}$ \\
\hline $\begin{array}{l}\text { WSHOP302 } \\
\text { Time management: developing strategies for managing } \\
\text { study, work and family commitments and understanding } \\
\text { the difference between being a virtuous student and } \\
\text { being an effective student. }\end{array}$ & $\begin{array}{l}\text { Sat } 5 \text { Oct } \\
2013 \\
10: 45- \\
11: 30 \\
\text { Room: GS3 }\end{array}$ & $\begin{array}{l}\text { Sat } 12 \text { Oct } \\
2013 \\
\text { 10:45 -11:30 } \\
\text { Room: M1- } \\
22\end{array}$ \\
\hline $\begin{array}{l}\text { WSHOP303 } \\
\text { Learning from lectures: understanding the value of } \\
\text { lectures, } \\
\text { how and what you can learn from them, how you can } \\
\text { prepare } \\
\text { and how to take notes }\end{array}$ & $\begin{array}{l}\text { Sat } 5 \text { Oct } \\
2013 \\
11: 45- \\
12: 45 \\
\text { Room: GS3 }\end{array}$ & $\begin{array}{l}\text { Sat } 12 \text { Oct } \\
2013 \\
11: 45-12: 45 \\
\text { Room: M1- } \\
22\end{array}$ \\
\hline $\begin{array}{l}\text { WSHOP304 } \\
\text { Introduction to E-Learning/Moodle: understanding the } \\
\text { advantages of online learning and learning how to use } \\
\text { Moodle. } \\
\text { N.B. This is not an introduction to computing. }\end{array}$ & $\begin{array}{l}\text { Sat } 5 \text { Oct } \\
2013 \\
13: 15- \\
14: 30 \\
\text { Room: } \\
\text { KSA1 }\end{array}$ & $\begin{array}{l}\text { Sat } 12 \text { Oct } \\
2013 \\
\text { 13:15-14:30 } \\
\text { Room: M1- } \\
22\end{array}$ \\
\hline $\begin{array}{l}\text { WSHOP305 } \\
\text { Research and Reading: planning your research, } \\
\text { selecting the } \\
\text { appropriate reading material and reading techniques }\end{array}$ & $\begin{array}{l}\text { Sat } 12 \text { Oct } \\
2013 \\
09: 30 \\
11: 00 \\
\text { Room: } \\
\text { KS17 }\end{array}$ & $\begin{array}{l}\text { Sat } 19 \text { Oct } \\
2013 \\
09: 30-11: 00 \\
\text { Room: M1- } \\
22\end{array}$ \\
\hline WSHOP306 & Sat 12 Oct & Sat 19 Oct \\
\hline
\end{tabular}




\begin{tabular}{|c|c|c|}
\hline $\begin{array}{l}\text { Note taking skills: taking notes from lectures, seminars } \\
\text { and } \\
\text { written material, making planning notes for } \\
\text { assignments. }\end{array}$ & $\begin{array}{l}2013 \\
11: 15- \\
12: 15 \\
\text { Room: } \\
\text { KS17 }\end{array}$ & $\begin{array}{l}2013 \\
11: 15-12: 15 \\
\text { Room: M1- } \\
22\end{array}$ \\
\hline $\begin{array}{l}\text { WSHOP307 } \\
\text { Critical thinking skills: presenting and evaluating an } \\
\text { argument } \\
\text { or line of reasoning, learning to identify and draw valid } \\
\text { conclusions. }\end{array}$ & $\begin{array}{l}\text { Sat 12 Oct } \\
2013 \\
12: 45 \text { - } \\
14: 00 \\
\text { Room: } \\
\text { KS17 }\end{array}$ & $\begin{array}{l}\text { Sat } 19 \text { Oct } \\
2013 \\
\text { 12:45 -14:00 } \\
\text { Room: M1- } \\
22\end{array}$ \\
\hline $\begin{array}{l}\text { WSHOP308 } \\
\text { Study clinics: an opportunity to discuss any study } \\
\text { related } \\
\text { issues with a learning advisor (20-minute, confidential } \\
\text { appointments). }\end{array}$ & $\begin{array}{l}\text { Sat 12 Oct } \\
2013 \\
14: 00- \\
15: 00 \\
\text { Room: } \\
\text { KS17 }\end{array}$ & $\begin{array}{l}\text { Sat } 19 \text { Oct } \\
2013 \\
\text { 14:00 -15:00 } \\
\text { Room: M1- } \\
22\end{array}$ \\
\hline $\begin{array}{l}\text { WSHOP309 } \\
\text { Essay planning: understanding essay questions and } \\
\text { planning to write }\end{array}$ & $\begin{array}{l}\text { Sat } 19 \text { Oct } \\
2013 \\
9.30-10.30 \\
\text { Room: GS3 }\end{array}$ & $\begin{array}{l}26 \text { Oct } \\
2013 \\
9.30-10.30 \\
\text { Room: M1- } \\
22\end{array}$ \\
\hline $\begin{array}{l}\text { WSHOP310 } \\
\text { Structuring and paragraphing: what goes into the } \\
\text { introduction, conclusion and paragraphs; organising and } \\
\text { linking ideas }\end{array}$ & $\begin{array}{l}\text { Sat } 19 \text { Oct } \\
2013 \\
10: 45- \\
11: 45 \\
\text { Room: GS3 }\end{array}$ & $\begin{array}{l}26 \text { Oct } \\
2013 \\
10.45-11.45 \\
\text { Room: M1- } \\
22\end{array}$ \\
\hline $\begin{array}{l}\text { WSHOP311 } \\
\text { Referencing and paraphrasing: how to use the literature } \\
\text { to support your ideas and practice in paraphrasing }\end{array}$ & $\begin{array}{l}\text { Sat } 19 \text { Oct } \\
2013 \\
12.00-13.00 \\
\text { Room: GS3 }\end{array}$ & $\begin{array}{l}26 \text { Oct } \\
2013 \\
12.00-13.00 \\
\text { Room: M1- } \\
22\end{array}$ \\
\hline $\begin{array}{l}\text { WSHOP312 } \\
\text { Study clinics: an opportunity to discuss any study }\end{array}$ & $\begin{array}{l}\text { Sat } 19 \text { Oct } \\
2013\end{array}$ & $\begin{array}{l}26 \text { Oct } \\
2013\end{array}$ \\
\hline
\end{tabular}




\begin{tabular}{|l|l|l|}
\hline $\begin{array}{l}\text { related } \\
\text { issues with a learning advisor (20-minute, confidential } \\
\text { appointments). }\end{array}$ & $\begin{array}{l}14.00-15.00 \\
\text { Room: GS3 }\end{array}$ & $\begin{array}{l}14.00-15.00 \\
\text { Room: M1- } \\
22\end{array}$ \\
\hline
\end{tabular}

